\title{
Success Factors for the Implementation of Build Operate Transfer (BOT) Projects in Kuwait
}

\author{
Hassan Sharaffudin ${ }^{1} \&$ Abdulla AL-Mutairi ${ }^{1}$ \\ ${ }^{1}$ Dept. of Business Administration, Arab Open University- Kuwait branch, Kuwait \\ Correspondence: Hassan Sharaffudin, Dept. of Business Administration, Arab Open University-Kuwait branch, \\ Kuwait. E-mail: Mutairi.A@gust.edu.kw
}

Received: June 1, 2015

Accepted: July 2, 2015

Online Published: August 22, 2015

doi:10.5539/ijbm.v10n9p68

URL: http://dx.doi.org/10.5539/ijbm.v10n9p68

\begin{abstract}
This study is set out to explore the attitudes of concessionaires and government officials in the implementation of BOT in Kuwait. To achieve this objective, a questionnaire has been distributed to concessionaires and government officials, in which they were requested to state to what extent they agree or disagree with the Critical Success Factors (CSFs) of implementing the BOT projects. The results of analyzing their responses revealed that there is an agreement between both parties toward the significant factor of favorable project management as CSFs of implementing the BOT projects. However, while the concessionaires raise stable political situation and appropriate project identification as priority, government officials give priority to the social responsibility represented by public safety and training local staff. Finally, the failure of BOT projects generates a loss to both parties, public and private sector, while the success requests a rational mission of both parties toward projects as well as government support as one of the CSFs for BOT project.
\end{abstract}

Keywords: Public-private partnerships, critical success factors, BOT projects, project management, privatization, public facilities, Kuwait

\section{Introduction}

Build-Operate-Transfer (BOT) (Note 1) has offered attractive business benefits over the traditional offshore subsidiary path and received a wide attention in finance literature. The main issue of literature is to explain government's opportunities to make use of the private sector's investment, management, and technology.

Empirical studies have shown that BOT concept has become a popular option for rapid scaling of operations, wider service offerings, lower infrastructure set-up costs and reduced time to operations. Furthermore, BOT might improve the pathways whereby private funds can be attracted to be invested in programs of public works or services within a framework of suitable contractual arrangements. However, these findings seem to be questionable for the Gulf Co-operation Council (GCC) countries due to the high level of government surpluses and worlds proven oil reserves.

The purpose of this article is to explore the attitudes of concessionaires and government officials in the implementation of BOT in the Kuwait. It attempts to give a clear description of Critical Success Factors (CSFs) by examining whether BOT is the most adequate financing model to mount major infrastructure projects especially when Kuwaiti officials are looking forward to the BOT projects as a mean to turn the state of Kuwait into a regional trade and financial center by achieving economic development and diversification. In addition, Kuwait is of interest because of the poor performance recorded by public sector as well as lower productivity and absence of competition. Moreover, it has a very limited research in the field of BOT and privatization which leads to direct towards understanding the success factors involved in the implementation of BOT and the roles of private and public sectors.

The following sections of the study are a brief review of related literature followed by previous studies, and an overview of Kuwaiti banks. The fifth section presents the data and the model used, the empirical results are offered in section six, and the paper ends with a conclusion.

\section{Related Literature and Previous Studies}

BOT model is an approach of financial agreements, and performs according to a unique form of financing method called Project Finance, with two main participants, namely host government and private sponsor. The 
host government is a public regulator that is responsible for issuing the permits, authorizations and the project license or concession. It might have an effect on the tariffs, tolls, fees and other vital aspects of the project. Private sponsor is portrayed by a board of investors or private entity in charge of $r$ designing, constructing the facility, supporting and operating the facility after deputizing for an agreed duration called the concession period and setting for financing these stages of the project life cycle. Both budget restrictions and the complexity of the public sector to meet today's requirements encourage the BOT model to be adopted in developing countries. According to Kagiannas et al. (2003) there are three types of reasons for investors' reluctance namely psychological, technological and financial reasons. The psychological reason refers to the feeling of the investor that the contribution of these investments is low, while the technological reason refers to the investor not being convinced of the performance of new energy technology and the feasibility of the project. The financial reason refers to the unwillingness of investor to stick with such type of investments.

In empirical literature, the role of implementing the BOT system was taken in various places (see for example, Marroitt \& Brown, 1991; Llanto, 2008; Chu, 1999; Qiao et al., 2001; Chan et al., 2010; Zhao \& Wang, 2010; Askar \& Gab-Allah, 2002; Lu et al., 2003; AbuShams \& Awamleh, 2004; Wibowo, 2004; Akhirini \& Marzuki, 2009; Subprasom \& Chen, 2005; Toor \& Ogunlana, 2009; Algarni et al., 2007; Cheung \& Chan, 2009; Khan et al., 2008; Bakri et al., 2009; Markom \& Ali, 2012; Yong \& Mustaffa, 2012; Ismail, 2013; Bokharey et al., 2010. Alhumoud et al., 2010; Mathew \& Ramaswamy, 2010; Kippiliand \& Aryasr, 2012; Gupta et al., 2013; Dahir, 2012; Mohammed et al., 2012; Babatunde et al., 2012; Emmanuel, 2014. Santoso et al., 2012. Karmperis et al., 2012; Cheung et al., 2012; Yusof \& Salami, 2013; Toulabi, 2013. Alinaitwe \& Ayesiga, 2013; Palapus \& Hanaoka, 2009; Shrestha, 2011). The following section reviews in brief of these studies.

Marroitt and Brown (1991) pointed out that there are great issues that will require resolution before any particular project can come on stream, and the resolution might require all parties involved in the project to adopt an open and innovative approach during negotiations. The researchers recommended that developers need to understand the requirements and concerns of the host utility, but the host utility has to understand what is motivating the developer and what he needs from his client in order to be able to marshal the very great resources. Llanto (2008) explored the experience of the Philippines with the employment of the BOT approach for infrastructure development. He stated the importance of the government providing a clear policy framework on the BOT approach for private to participate in infrastructure stipulation. Moreover, the BOT law must be regarded as the principal enactment that substantiates government policy, and the institutional framework for applying BOT. Llanto recommended that the BOT statute or official policy declaration needs to permit the private advocate to impose user charges providing a return tantamount to the opportunity expense of its invested budget.

Chu (1999) examined the successful implementation of a Build-Own-Operate-Transfer (BOOT) approach in Australia. He found that by adopting a BOOT approach to the procurement of energy-related assets, a facility owner can expect to reap a number of benefits such as better risk allocation and operational efficiency. Chu observed that adopting a 'blend in' rather than a 'muscle in' approach to the relationship with the principal having the financial standing and experience to manage the risks of long-term asset stewardship.

Qiao et al. (2001) used a questionnaire survey to identify the attitudes of foreign investor and government officers towards the CSFs in implementing the BOT system in China. They found that there is a positive agreement between foreign investors and government officials on the importance of these CSFs. They provided evidence that an appropriate project identification and stable political and economic environment are the main determinants for CSFs of BOT. Zhao and Wang (2010) examined the social impact assessment for BOT/PPP projects in China. They found that the number of employees during construction and operation is different; in the former phase the number is large, while in the latter phase is small. They also found that decision-making of $\mathrm{BOT} / \mathrm{PPP}$ is a complicated process, involving various problems. Besides, it has a characteristic of hard cooperation among participations and high risks.

Askar and Gab-Allah (2002) examined the potential for implementing the BOT system in the Egyptian environment. They found that picking the right project, competitive financial proposal, and special features of bid are essential for the success of BOT projects in Egypt. They also found that there are four risks namely Political Risks, Construction Risks, Operating Risks and Market and Revenue Risks. Askar and Gab-Allah concluded that the risk factors should be minimized to ensure successful implementation of BOT projects. These findings are confirmed by Lu et al. (2003) in Taiwan.

AbuShams and Awamleh (2004) examined the potential for implementing the BOT system in the Jordanian environment. They found that the BOT contract is a good step towards specified operation and management of 
facilities in Jordan's Water and Wastewater Sector. They also found that the role of the private sector participation is expanded to transfer management of infrastructures and services to improve performance and upgrade the level of service. AbuShams and Awamleh concluded that the use of BOT contract will relieve the government of Jordan from the financial burden of capital investment.

Subprasom and Chen (2005) found that the BOT network design problem involves three parties, including the private sectors, the government, and the road users, in which each of these parties has distinctive objectives. They observed the impact of regulation and various policies that are implemented of the project performances and financial feasibility of private sectors. Subprasom and Chen concluded that regulation and policy are imposed by the government to ensure that the BOT project satisfies certain requirements. Toor and Ogunlana (2009) conducted around 76 questionnaire surveys and 35 interviews to figure out the CSFs on construction projects. They found that participants voiced their high apprehension for sufficient resources, proper communication, mutual understanding of stakeholders on project objectives, and grant of bids to the 'right' designers and contractors.

Algarni et al. (2007) used a questionnaire survey of large metropolises and state departments of transportation to adjudicate the extent to which they are using BOT is being used in their grand projects and explore the implementation of BOT. They discovered that most of the government agencies surveyed are unable to argue for the application of BOT on account of there being alternative methods of delivery/financing present with considerable success. Algarni et al. reached the conclusion that BOT is an option to construct infrastructure with the financial aid of the private sector when governments suffer from inadequacies of financial resources.

Cheung and Chan (2009) examined whether BOT is the superlative financing model to achieve major infrastructure projects in Hong Kong. They detected several reasons that caused the case to be financed by the government instead of entailing the private sector as primarily intended. First, Hong Kong had previously undergone a lack of interest from the private sector which led the project delay for repackaging. Second, the legal disparities between the three authorities would denote that an agreement unifying and intermediary between all legal systems would be challenging.

Third, with private sector involvement, the government would be unable to exercise control over the toll prices. Finally, the most significant motive of all is that the three governments have relaxed financial reserves, which translates into their preparedness to deliver the project themselves comfortably.

Khan et al. (2008) examined the implementation of BOT in the Pakistani system. They found that the notion of BOT in Pakistan is yet novel. So it needs to be presented to the Pakistani construction industry and organizations through presentations, lectures, seminars etc. They also recommended that in order to share success, the stakeholders of commenced BOT projects ought to be referred to others. They found that political instability is the major political inhibition experienced in the decision making of the organizational management structures to initiate its projects in Pakistan. Furthermore, they advised that the benefits attained from the BOT projects should be emphasized in media to attract the attention of local and foreign investors.

Bakri et al. (2009) investigated the level of awareness among pertinent participants in the application of BOT projects in Malaysia and to pinpoint the risks linked with Malaysia's BOT infrastructure projects particularly roads and highway projects. They incited some items which lead to a win-win situation for both the government and the investors, including the idea that the project must offer a considerable rate of return so as to attract private investments, a solid mechanism to fix and regulate toll rates and a legal framework to defend both parties' interests.

Markom and Ali (2012) discovered that there are widespread fundamental factors contributing to the success of BOT projects such as: firm policy and regulatory framework, powerful government support, transparency of project formulation and documentation, reliable sponsors and impartial deals for all parties. They also detected that the factors contributing to the burdensome projects are individualized. Markom and Ali arrived at the conclusion that measures to surmount the problems are clarified to enhance the efficacy and productiveness of both BOT legal technique and privatization as a whole. Yong and Mustaffa (2012) added that a remarkable consistency in conception between respondents in acknowledging the importance of human-related factors such as capability, devotion, communication and collaboration for the success of a construction project. Ismail (2013)utilized questionnaire survey to explore the significance of the success factors in Malaysia. Hedetected that "good governance", "commitment of the public and private sectors", "favorable legal framework", "sound economic policy" and "availability of finance market" are the top five success factors of PPP implementation in Malaysia.

Alhumoud et al. (2010) examined the implementation of BOT contract to a local company to finance, design, 
build and operate an advanced wastewater treatment plant (WWTP) at Sulaibiya in Kuwaiti environment. The contract has a 30-year life, comprising 30 months of design and build and 27.5 years of operation and management. They found the main obstacle against the use of ultrafiltration membranes for WWTP has always been the higher operating cost of ultrafiltration.

Bokharey et al. (2010) examined the associated risk with BOT project. They recommend that the host government should play more active role by providing guarantees for a BOT project that will benefit the public. They also recommended that the lender and investor should conduct feasibility studies before they finance a BOT project. Bokharey et al. concluded that a comprehensive risk management for any BOT project should be conducted and the mitigation plan must be followed strictly in ensuring the success of the project.

Dahir (2012) examined the understanding and development transfer of technology through BOT projects development in Nigeria. He found that the problem of transfer technology process of BOT is related to time constraint, lack of trust, lack of effective value and the fear of losing the competitive edge. He pointed that the government needs to provide supportive policies and strategies in BOT agreement for technology transfer consideration to the relevant parties. He concluded that government and concessionaire can use the findings efficiently to design technology transfer framework that can be sued to overcome the problems encountered.

Mohammed et al. (2012) used questionnaire survey to examine implementing the BOT system. They found four risks, including political risks, construction risks, operating risks and market and revenue risks. They stated factors leading to success including picking the right project, competitive financial proposal and special features of bid. Mohammed et al. suggested that the risk factors should be minimized to ensure successful implementation of BOT projects. Babatunde et al. (2012) argued that a well-organized and committed public agency seem to be the most important factors to the private investors. They also found that factors such as transparency in the procurement process and shared authority between public and private sector are the CSFs that are most consequential to the public clients. Recently, Emmanuel (2014) discovered that CSFs for thriving PPP implementation are clear and strong regulatory framework, all-inclusive feasibility study and apt risk allocation amongst others. He also found that some CSFs such as dedication and accountability of public and private sectors, firm private society and certifiable cost/benefit assessment amongst others are indispensable for PPP implementation. Emmanuel recommended that the government should be involved in multiple PPP projects to create the much needed market for PPP implementation.

Santoso et al. (2012) studied the key risk events for public-private partnerships in Indonesian tollway construction and operation. They found that land acquisition problems, which represent the major risks in the top-ranked risk event list, lie mainly under the control of the government. They also observed that land acquisition is still a major problem in terms of time and money. The delays and budget overruns in land acquisition are not only the first two risk events with the highest risk index, but they are also the first- and second-ranked items for degrees of risk impact and occurrence.

In Greece, Karmperis et al. (2012) examined the correlation between the financial sustainability evaluation and the quantitative risk analysis of waste treatment projects, which are applied with BOT contracts. They employed a formula for the investor's profit rate calculation, which corresponds to constant cash influx throughout the project's operational phase and ensures the partnership's financial sustainability.

Cheung et al. (2012) investigated the Critical Success Factors (CSFs) required for implementing Public Private Partnerships (PPPs) in both mainland China and Hong Kong. They discovered that both mainland China and Hong Kong have been eager to present more infrastructure service projects through PPP mode, with the former aspiring to cope it's hastily growing infrastructure demand and the latter elevating its efficacy further. They also found that Hong Kong does not perceive multi-benefit objectives as substantially as mainland China. Mainland China, on the other hand, was more interested with an impartial risk sharing mechanism, which is apprehensible given the issues influencing the financial market in mainland China.

Yusof and Salami (2013) distributed questionnaire survey to government organization, consultants, and concessionaires to determine the success factors in BOT power plant projects in Iran. They found that apt project identification, stable political situation, favorable legislation regulation, and well-organized and committed public agency are the most important factors. They also found that there are no significant differences between consultants, government organization, and concessionaires with respect to the success factors in BOT power plant projects in Iran. Toulabi (2013) examined the potential for implementing the BOT system in the Iranian environment. They found that there is a need to identify criteria for project success.

Alinaitwe and Ayesiga (2013) used questionnaire surveys to explore the success factors for Public-Private Partnership (PPP) projects in Uganda. They discovered that the five factors that are perceived to be of utmost 
significance to the public sector are a well-organized public agency, a competitive procurement process, project financial achievability, devotion of all of the parties, and a firm monitoring and evaluation system for the projects implemented. They also found that the five factors for the financial sector are a competitive procurement process, the presence of an empowering PPP policy, an empowering environment for local private construction companies to contend complimentarily and proliferate compared to internationals and multinationals, sound governance; and a streamlined, transparent and clear project appraisal policy.

Mathew and Ramaswamy (2010) used a questionnaire survey to quantify the risks actually faced by the BOT projects in Kerala. They found that public opposition and local conditions, politics and uncertainty about other actors are most political risks. They also found that availability of funds and change in cost of project are the most financial and commercial risk. Mathew and Ramaswamy concluded that comprehensive risk management for any BOT project should be conducted and the mitigation plan must be followed strictly in ensuring the success of the project. Kippiliand and Aryasr (2012) examined the implementation of BOT in Indian environment. They found that the model is applicable solely in the case where the international companies have plans to maintain the operations in the targeted region for a fairly longer time after transition. Kippiliand and Aryasr recommended adopting the BOT model if the service provider has conceded to transfer all levels of resources. Gupta et al. (2013) also mentioned that Concession agreement, short-construction period, selection procedure of concessionaire, sufficient long-term demand and sufficient net cash inflow surfaced as the top five factors vital for the success of the BOT projects in India.

Palapus and Hanaoka (2009) examined the rail projects implemented through BOT in some Asian countries to identify the strengths and weaknesses resulting in the current status of these projects. They observed that without the partnership with the private sectors, these projects may have not been realized. They recommended that due to the government's limited resources and the huge amount of investment at stake, management of risks associated in all stages of implementation should be given critical focus both by the government and the private sector to ensure success of BOT projects.

Shrestha (2011) examined the potential for implementing the BOT system in the Nepal. He pointed out that the BOT model of investment can play a significant role in meeting the demand. He also found that the success of BOT projects would depend on Improvement of the country's legal, political and institutional framework for BOT and the demonstration of an attractive and conducive investment environment with rule of law, transparency and accountability. Shrestha concluded that Nepal must seriously consider having more BOT projects, especially in its urgently needed infrastructure such as Hydropower generation, roads, bridges, telecommunications, water supply, waste disposal, etc.

The above findings show that there are some factors that face implementing BOT projects. For Kuwait State, there are a limited number of empirical studies; this suggests the need for an empirical testing of BOT since these projects well endow Kuwait with a substantial infrastructure investment. Since Kuwait economy depends mainly on oil resources, BOT projects seem to be an alternative plan that compensate the decline in oil revenues, therefore the importance of the present research.

\section{Research Methodology}

\subsection{Instrument}

A questionnaire consists of two main sections: general information of participants and CSFs. The questionnaire was developed by the researchers according to the purpose of the study. The questionnaire was reviewed by five university professors at AOU-Kuwait branch and Kuwait University to reach the high level of validity and modified according to their suggestions and recommendations. As a result, new questions were added and others were adapted. The modified questionnaire contained nineteen 5- point Likert scale items. The questionnaire allows the participants to rate each of the 19-factor items on a five-point scale ranging from strongly disagree (1) to strongly agree (5) where (3) stood for a neutral response.

It is worth to be mentioned that previous studies have used this scale such as Askar and Gab-Allah (2002) in Egypt, Ismail (2013) in Malaysia, Lu et al. (2003) in Taiwan, Karmperis et al. (2012) in Greece and Yusof and Salami (2013) in Iran. The questionnaire had a Cronbach's alpha co-efficient of 0.82, indicating high internal consistency of the items (Qiao et al., 2001).

\subsection{The Procedure}

Research methodology consists of two phases. The first phase covers related literature and previous studies of major stakeholders in BOT. The reason behind this phase refers to the identification on the attitudes of stakeholder towards the implementation of BOT projects. The second phase is developing the questionnaire as a 
main tool for the current study. The questionnaire includes closed questions and will be distributed between two main stakeholders: government officers and concessionaires. The reason behind selecting closed questions refers to searching for the convenience and absence of interviewer impact. The data gathered were entered to SPSS for comprehensive analysis based on the objectives of the study. The data was analyzed for descriptive statistics for all independent and dependent variables. In addition, a mean and standard deviation were performed to examine the significance of differences in the respondents' opinions about the factors that may lead to CSFs.

\subsection{The Survey Sample}

The questionnaire survey attempted to explore some obstacles that BOT project encountered. Thus, it was dealt with BOT participants involved in Kuwait and distributed to government officials and concessionaires.

Table 1. Distributed, returned, and missing questionnaire comparison

\begin{tabular}{llll}
\hline & Description & Quantity & Percentage (\%) \\
\hline 1 & Questionnaire distributed & 120 & 100 \\
2 & Questionnaire returned & 95 & 79 \\
3 & Questionnaire valid and returned & 90 & 75 \\
4 & Missing & 30 & 25 \\
\hline
\end{tabular}

A total of 120 questionnaires were distributed to BOT specialists according to two above types and 95 questionnaires were gathered. From this number, 90 questionnaires were considered as valid questionnaires for analysis (Table 1).

\section{Respondents' background}

Table II summarizes background statistics of the participants who took part in the survey. The table reveals that the majority of the participants ( 89 percent) are Kuwaitis and the rest (11 percent) are non-Kuwaitis. It also shows that the majority of the participants ( 60 percent) are male and ( 30 percent) are female.

Table 2. Informational background about the respondents

\begin{tabular}{lll}
\hline Characteristics & Frequency & Percent \\
\hline $\begin{array}{l}\text { 1)Type of participant } \\
\text { a) Concessionaires }\end{array}$ & 45 & 50 \\
b) Government officials & 45 & 50 \\
2)Nationality & & \\
a) Kuwaiti & 80 & 89 \\
b) Non-Kuwaiti & 10 & 11 \\
3)Gender & & \\
a) Male & 60 & 67 \\
b)Female & 30 & 33 \\
4)Level of education & & \\
a)high school & 0 & 0 \\
b)Diploma & 10 & 11 \\
c) University Degree & 70 & 78 \\
d)Master level & 10 & 11 \\
5) Participant age & & \\
a) less than 25 year old & 8 & 9 \\
b)from 25 to 35 year old & 18 & 20 \\
c) from 35 to 50 year old & 54 & 60 \\
d)More than 50 year old & 10 & 11 \\
6) Participant experience & & \\
a) less than 5 years & 5 & 5.6 \\
b)from 5 to 10 years & 20 & 22 \\
c) from 10 to 20 years & 26 & 29 \\
d)More than 20 years & 39 & 43 \\
\hline
\end{tabular}


Table 2 also shows that more than 90 percent of participants' ages are below 50 years, suggesting the domination of the young generation on the Kuwaiti economy in entrepreneurship. It demonstrates that the majority of the participants (90 percent) have a university degree suggesting the high academic qualifications of people who are working in BOT projects

Table 3. Views of concessionaires government and officials about success factors in BOT projects

\begin{tabular}{llllllll}
\hline & \multicolumn{3}{l}{ Concessionaires (N=45) } & \multicolumn{2}{l}{ Government Officials (N=45) } & Sig. \\
\hline Factor & Mean & S.D. & Rank & Mean & S.D. & Rank & .37 \\
\hline Stable political situation & 4.6 & .74 & 1 & 4.1 & .73 & 13 & .89 \\
appropriate project identification & 4.6 & .76 & 2 & 4.3 & .97 & 8 & .36 \\
Favorable project management & 4.4 & .93 & 3 & 4.6 & .74 & 1 & .67 \\
Good relationship with government & 4.4 & .84 & 4 & 4.1 & 1.1 & 14 & .69 \\
Reasonable risk allocation & 4.3 & .73 & 5 & 4.3 & .72 & 10 & .83 \\
Government support & 4.3 & 1.1 & 6 & 3.8 & .98 & 17 & .10 \\
Attractive financial package & 4.2 & 0.7 & 7 & 4.2 & 1.0 & 12 & .05 \\
Utilize local company in project company & 4.2 & 1.1 & 8 & 3.3 & 1.2 & 19 & .66 \\
Financial market availability & 4.2 & .97 & 9 & 4.4 & .86 & 7 & .63 \\
Favorable legislation regulation & 4.1 & 1.3 & 10 & 4.5 & .6 & 4 & .16 \\
Short concession period & 4.1 & 1.2 & 11 & 3.4 & 1.3 & 18 & .80 \\
A multidisciplinary and multinational team & 4.1 & 1.1 & 12 & 4.4 & .68 & 6 & .74 \\
Quality control and supervision & 4.1 & .95 & 13 & 4.5 & .75 & 5 & .20 \\
Training local staff & 4 & .88 & 14 & 4.6 & .66 & 3 & .88 \\
Technology transfer & 3.9 & .83 & 15 & 4.3 & .78 & 11 & .34 \\
Experience with BOT project by public sector & 3.9 & 1.4 & 16 & 4.3 & .8 & 9 & .14 \\
Sound environment impact & 3.9 & .77 & 17 & 4.0 & 1.1 & 15 & .10 \\
Public safety & 3.9 & .95 & 18 & 4.6 & 0.6 & 2 & .97 \\
Social support & 3.79 & 1.1 & 19 & 3.9 & 0.8 & 16 & \\
\hline
\end{tabular}

A number of success factors that may influence the adoption of BOT were listed in the questionnaire and both participants, concessionaires and government officials, were asked to give their degree of agreement about each of them. The result of the analysis is reported in Table 3. It is obvious that the both participants believe that favorable project management is the main reason behind the respondents' decision to adopt BOT. This finding is confirmed by the mean and the standard deviation. The findings are consistent with the result reached by Yusof and Salami (2013) who reported that favorable project management is one of the main determinants for CSFs of BOT in Iran.

Nineteen success factors have been considered to recognize participants' views in these two groups including government officials (50 persons) and concessionaires $(50$ persons). The mean scores assigned by concessionaires to stable political situation, appropriate project identification, favorable project management and good relationship with the government are greater than 4.40. This indicates that these four factors are the most important factors in view of concessionaires. A stable and supportive political climate is a precondition for successful application of the BOT project. The findings are consistent with the result reached by Qiao et al., (2001) who reported that stable political situation, appropriate project identification are the main determinants for CSFs of BOT to foreign investor in China. One of the indicators related to this analysis is that political laws in Kuwait play an important role in determining the economic system. In order to establish any mega project, parliamentarians' approval has to be obtained because it has great impact over the state's economy. Proper examination and determination of its positive and its negative consequences are therefore conducted to ensure a smooth implementation of the project.

The above table also shows that training local staff and public safety are less important to concessionaires. The possible explanation for this finding is attributed to the fact that concessionaires are looking for maximization of wealth and these items might have negative influence on this goal. The findings are consistent with the result reached by Yusof and Salami (2013) who reported that training local staff is less important to concessionaires in Iran and Gupta (2012) who reported that Safety considerations are less important to concessionaires in India. Moreover, the findings are inconsistent with the result reached by Qiao et al. (2001) who reported that training local staff is more important to foreign investors in China. 
It appears that the mean scores assigned by government officials to favorable project management, public safety and training local staff are greater than 4.60. It reflects the government attention on social responsibility. The above findings are consistent with the result reached by Qiao et al. (2001) who reported that training local staff is an important determinant for CSFs of BOT to foreign investors in China. However, they are inconsistent with the result reached by Yusof and Salami (2013) who reported that training local staff is less important to government officials in Iran and by Qiao et al. (2001) who reported that public safety is less important to foreign investors in China.

Table 3 also shows that utilizing local companies in projects, short concession period and government support are less important to government officials. The possible explanation for this finding is attributed to the fact that government officials believe that the time period and government support are given to all projects. The findings are consistent with the result reached by Yusof and Salami (2013) who reported that short concession period is less important to government officials in Iran. In addition, the investors are expecting a change in laws according to different circumstances, for instance the new BOT law in Kuwait, known as Public Private Partnership (PPP), gives opportunity for new investors to extend the project period to 50 years; whilst current ones are not entitled to extend more than one year. This policy endangers investors and exposes them to huge financial losses. This is an important issue especially that we are living in a changing economic climate and we are not certain about future circumstances.

In short, there is an agreement between two parties' government officials and concessionaires about the significant role of favorable project management as the success factor in BOT projects. This finding can be seen clearly in establishing and investing in different socioeconomic projects such as: Shadadiyah University Campus (investing in human capital), developing Failaka Island (tourism sector), Bubian Island (and its importance to extend the Kuwaiti ports in the Gulf) and Jaber Al Ahmed Al Sabah Hospital. However, there is a disagreement among both parties towards the social responsibility. While government officials give priority to the social responsibility represented by public safety and training local staff, concessionaires consider social responsibility as a less important success factor.

\section{Conclusion}

In this study, an attempt was made to investigate CSFs for BOT projects in Kuwait. In the literature, the CSFs were categorized into tangible and intangible factors in a systematic way. According to extensive literature review, this research establishes success factors for BOT project in Kuwait, comprising 19 factors. These factors were put into a questionnaire and the questionnaire was distributed to 120 participants, covering two types of participants namely government officials and concessionaires. Of them, 90 (75 percent response rate) questionnaires were completed and formed a basis for the empirical part of this study. The findings of questionnaire were obtained from seniors in middle and top level management.

It was evident from the analysis that favorable project management is an important factor in view of both concessionaires and government officials. The analysis also revealed that the government officials attempt to raise the social responsibility. It seeks to enhance private sector for training local staff and public safety. Thus, the success factor of social responsibility and favorable project management are considered the most important factors for government officials.

Furthermore, it appears from the analysis that concessionaires depend upon revenues to pay for operating cost cover debt financing. Thus, a stable political situation and favorable legislation regulation are considered as the most important factors in view of the concessionaires.

It is worth mentioning that the failure of BOT projects generates a loss to parties, the public and private sectors. Therefore, the success of a BOT project demands a rational mission of both parties by understanding and managing the risks. It is fair to say that government support is one of the CSFs for the BOT project. Therefore, there is a need to develop guidelines that helps the government in providing a supportive environment for the BOT projects.

Although this study was limited to the perspective of CSFs for the BOT project in Kuwait and demands great consideration by parties, the government and concessionaires to ensure successful implementation, it may encourage the CSFs for BOT project in GCC region. Another important area that merits to be empirically researched is risk analysis between the public and private partners and mechanisms for risk mitigation and management.

\section{Acknowledgments}

This work was supported by a grant from the Arab Open University-Kuwait branch. The authors would like to 
express their special tokens of gratitude to the research committee for its support and guidance. We would also like to thank all of those who participated in the questionnaire and those who helped in collecting the data and information. Special thanks to our academic colleagues for their constructive criticism and friendly advice during the paper work.

\section{References}

AbuShams, I., \& Awamleh, M. (2004). Public private partnership through, build-operate transfer in Jordan waste water sector. Eighth International Water Technology Conference, IWTC8 2004, Alexandria, Egypt. Retrieved from http://www.iwtc.info/2004_pdf/05-3.pdf

Akhirini, P., \& Marzuki, F. (2009). Identification and analysis of risk factors in BOT Toll Road projects: An Indonesian study. Retrieved from http://www.ftsl.itb.ac.id/wp-content/uploads/2009/12/identification-and-analysis-of-risk-factors-in-bot-toll-r oad-projects.pdf

Algarni, A., Arditi, D., \& Polat, G. (2007). Build-Operate-Transfer in Infrastructure Projects in the United States. $\begin{array}{llll}\text { Journal of Construction Engineering and } & \text { 728-735. }\end{array}$ http://dx.doi.org/10.1061/(ASCE)0733-9364(2007)133:10(728)

Alhumoud, J., Al-Humaidi, H., Al-Ghusain, I., \& Alhumoud, A. (2010). Cost/benefit evaluation of Sulaibiy a waste water treatment plant in Kuwait. International Business \& Economics Research Journal, 9(2), 23-32.

Alinaitwe, H., \& Ayesiga, R. (2013). Success factors for the implementation of public-private partnerships in the construction industry in Uganda. Journal of Construction in Developing Countries, 18(2), 1-14.

Askar, M., \& Gab-Allah, A. (2002). Problems facing parties involved in build, operate, and transport projects in $\begin{array}{llll}\text { Egypt. Journal of } & \text { Management in }\end{array}$ http://dx.doi.org/10.1061/(ASCE)0742-597X(2002)18:4(173)

Babatunde, S., Opawole, A., \& Akinsiku, O. (2012). Critical success factors in public-private partnership (PPP) on infrastructure delivery in Nigeria. Journal of Facilities Management, 10(3), 212-225. http://dx.doi.org/10.1108/14725961211246018

Bakri, A., Khaderi, Sh., \& Abd, Sh. A. (2009). Risk management in build-operate-transfer (BOT) for roads and highway projects in Malaysia. Built Environment Journal, 6(1), 1-11

Bokharey, S., Vallyutham, K., Potty, V., \& Abu Bakar, N. (2010). Risks and mitigation measures in buildoperate-transfer projects. World Academy of Science, Engineering and Technology, 39, 217-223

Chan, A., Lam, P., Chan, D., Cheung, E., \& Ke, Y. (2010). Critical success factors for PPPs in infrastructure developments: Chinese perspective. Journal of Construction Engineering and Management, 136(5), 484-494.

Cheung, E., \& Chan, A. (2009). Is BOT the best financing model to procure infrastructure projects? A case study of the Hong Kong-Zhuhai-Macau Bridge. Journal of Property Investment \& Finance, 27(3), 290-302, http://dx.doi.org/10.1108/14635780910951984

Cheung, E., Chan, A., Lam, P., Chan, D., \& Ke, Y. (2012). A comparative study of critical success factors for public private partnerships (PPP) between Mainland China and the Hong Kong Special Administrative Region. Facilities-Special Issue on Facility Management Development, 30(13/14), 647-666, http://dx.doi.org/10.1108/02632771211273132

Chu, J. (1999). The BOOT approach to energy infrastructure management: A means to optimise the return from facilities. Facilities, 17(12/13), 492-498, http://dx.doi.org/10.1108/02632779910293497

Dahir, A. (2012). Factors influencing technology transfer process in build-operate-transfer (BOT) projects in Nigeria. Journal of Environment Technology, 5(1), 60-77.

Dey, P., \& Ogunlana, S. (2004). Selection and application of risk management tools and techniques for build-operate-transfer projects. Industrial Management \& Data Systems, 104(4), 334-346.

Emmanuel, O. (2014). Critical success factors (CSF) determining the implementation of public-private partnership projects. Covenant Journal of Research in the Built Environment, 1(2), 41-66.

Gupta, A., Gupta, M., \& Agrawal, R. (2013). Identification and ranking of critical success factors for BOT projects in India. Management Research Review, 36(11), 1040-1060. 
Ismail, S. (2013). Critical success factors of public private partnership (PPP) implementation in Malaysia. Asia-Pacific Journal of Business Administration, 5(1), 6-19, http://dx.doi.org/10.1108/17574321311304503

Kagiannas, A., Patlitzianas, K., \& Psarras, J. (2003). The role of Build Operate Transfer in promoting RES projects. Retrieved from http://www.opet-chp.net/download/wp6/epuntua_theroleofbuildoperatetransferinpromotingresproject.pdf

Karmperis, A., Tatsiopoulos, I., Sotirchos, A., \& Aravossis, K. (2012). On the financial and risk analysis of waste treatment projects in Greece. International Journal Development and Planning, (2), 252-263.

Katz, G. \& Smith, S. 2003. Build-operate-transfer: The future of public construction? Journal of Construction Accounting \& Taxation, 13(2), 36-48.

Khan, A., Jamil, M., \& Sattar, M. (2008). The trend of build operate and transfer (BOT) projects in Pakistan, First International Conference on Construction in Developing Countries (ICCIDC-I), Advancing and Integrating Construction Education. Research \& Practice, Karachi, Pakistan.

Kippili, M., \& Aryasr, A. (2012). Financial analysis of build-operate-transfer (BOT) model: A case study for semiconductor industry. Pacific Business Review International, 5(3), 5-23.

Llanto, G. (2008). A review of build-operate-transfer for infrastructure development: Some lessons for policy reform. Retrieved from http://www.eaber.org/sites/default/files/documents/PIDS_Llanto_2008_02.pdf

Lu, Ch., Tsao, Ch., Tzeng, K., \& Goo, Y. (2003). Using market risk capital concept to assess minimum capital requirement financial proposal of BOT project- A case study on container terminal in Taipai port. Journal of the Eastern Asia Society for Transportation Studies, 5(October), 638-650.

Markom, R., \& Ali, E. (2012). A legal analysis of successful and problematic build operate and transfer (BOT) projects in Malaysia. International Journal of Business and Society, 13(2), 133-150.

Marroitt, G., \& Brown, D. (1991). Build-operate-transfer geothermal power development, Proc $13^{\text {th }}$ New Zealand workshop (pp. 63-68). http://www.geothermal-energy.org/pdf/IGAstandard/NZGW/1991/Marriott.pdf

Mathew, B., \& Ramaswamy, K. (2010). Risk assessment and management in build operate and transfer (BOT) infrastructure projects in Kerala. International Conference on Technological Trends, College of Engineering, Trivandrum, Kerala.

Mohammed, I., Bala, K., \& Kunya, S. (2012). Risk in build, operate and transfer (BOT) projects in Nigeria. Journal of Environmental Science and Resource Management, 4(June), 29-39.

Nandi, R., \& Tiwari, S. (2012). State of affairs of build-operate-transfer project. International Journal of Science and Advanced Technology, 2(4), 164-170.

Palapus, H. \& Hanaoka, Sh. (2009). Build-operate-transfer challenges in Asian rail projects. Retrieved from http://library.jsce.or.jp/jsce/open/00039/200911_no40/pdf/322.pdf

Qiao, L., Wang, Sh., Tiong, L., \& Chsn, T. (2001). Framework for critical success factors of BOT projects in China. The Journal of Project Finance, 53-61.

Santoso, D., Joewono, T., Wibowo, A., Sinaga, H., \& Santosa, W. (2012). Public-private partnerships for Tollway construction and operation: Risk assessment and allocation from the perspective of investors. Journal of Construction in Developing Countries, 17(2), 45-66.

Shrestha, S. (2011). Prospects of BOT (Build-Operate-Transfer) projects for infrastructure development in Nepal. Journal of the Institute of Engineering, 8(1), 138-142.

Subprasom, K., \& Chen, A. (2005). Analysis of policy and regulation on build-operate transfer scheme: A case study of the Ban Pong-kanchanaburi motorway in Thailand. Journal of the Eastern Asia Society for Transportation Studies, 6, 3883-3898.

Toor, Sh., \& Ogunlana, S. (2009). Construction professionals' perception of critical success factors for large-scale construction projects. Construction Innovation, 9(2), 149-167.

Toulabi, H. (2013). Identify criteria success for BOT projects in Iran. Advances in Environmental Biology, 7(8), 2037-2040.

Wibowo, A. (2004). Valuing guarantees in a BOT infrastructure project. Engineering, Construction and Architectural Management, 11(6), 395-403. http://dx.doi.org/10.1108/09699980410571543 
Yong, Y., \& Mustaffa, N. (2012). Analysis of factors critical to construction project success in Malaysia. Engineering, Construction and Architectural Management, 19(5), 543-556.

Yusof, A., \& Salami, B. (2013). Success factors for build operate transfer (BOT) power plant projects in Iran. International Journal of Modern Engineering Research, 3(1), 324-330.

Zhao, G., \& Wang, Sh. (2010). Indicators of social impact assessment for BOT/PPP projects. Proceedings of the International Symposium on Social Management Systems (ISMSZOO7).

\section{Note}

Note 1. BOT: Build refers to the setting up of the facility and infrastructure, staffing the development center, and establishing knowledge transfer. Operate refers to managing the offshore organization: programming management, development, QA, maintenance, enhancements, and product support. Transfer refers to registering a new offshore subsidiary for the customer, transferring assets, and handing over operations.

\section{Copyrights}

Copyright for this article is retained by the author(s), with first publication rights granted to the journal.

This is an open-access article distributed under the terms and conditions of the Creative Commons Attribution license (http://creativecommons.org/licenses/by/3.0/). 